Nevada

Environmental

Restoration

Project

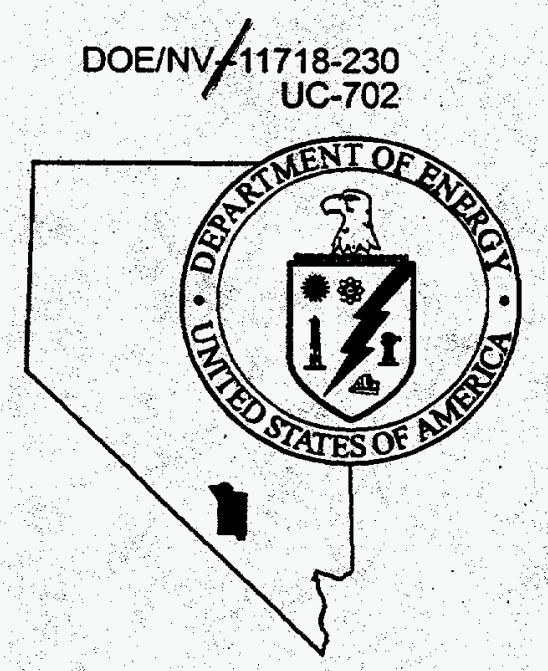

Streamlined Approach for

Environmental Restoration

Work Plan for

Corrective Action Unit 126:

Closure of Aboveground

Storage Tanks

Nevada Test Site, Nevada

Controlled Copy No.:

Revision: 1

DSTRBUTION OF THIS DOCUMENT IS UNLMUTED

July 1998

MASTER

Environmental Restoration

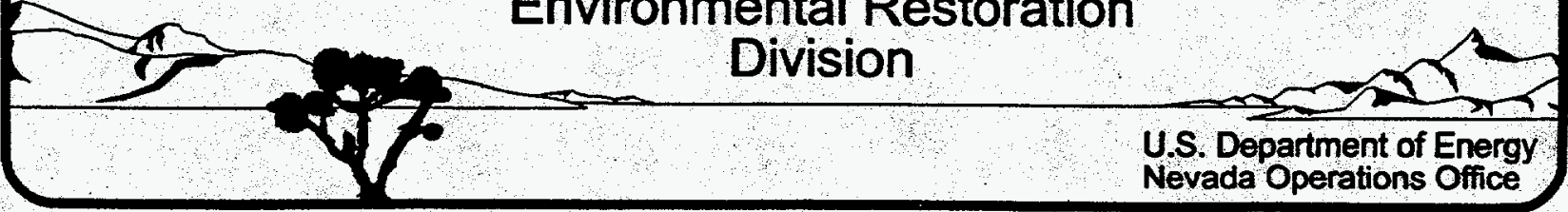


This report has been reproduced from the best available copy.

DOE and DOE contractors can obtain copies of this report from the Office of Scientific and Technical Information, P.O. Box 62, Oak Ridge, TN 37831, (423) 576-8401.

This report is publicly available from the National Technical Information Service, U. S. Department of Commerce, 5285 Port Royal Road, Springfield, VA, 22161, (703) 487-4650. 


\section{DISCLAMER}

This report was prepared as an account of work sponsored by an agency of the United States Government. Neither the United States Governmeat nor any agency thereof, nor any of their employees, makes any warranty, express or implied. of essumes any legal liability or tesponsibility for the accuracy, compieteress, or usefulness of any information. apparatus, produce, or process disclosed or represents that its use would not infriage privately owned rights. Reference berein to any spe. cific commercial product, process, or service by trade name. tradernarta marufacturer. or otherwise does not necessarily constitute or imply its esdorsement. recommendation. or favoring by the United States Governmeat or any agency thereof. The views and opinions of authors expressed herein do not necessarily rate or reflect those of the. United States Governmeat or any agency thercof. 


\section{DISCLAIMER}

Portions of this document may be illegible in electronic image products. Images are produced from the best available original document. 


\title{
STREAMLINED APPROACH FOR ENVIRONMENTAL RESTORATION WORK PLAN FOR CORRECTIVE ACTION UNIT 126: CLOSURE OF ABOVEGROUND STORAGE TANKS NEVADA TEST SITE, NEVADA
}

\author{
Prepared for \\ U. S. Department of Energy \\ Nevada Operations Office \\ Under Contract No. DE-AC08-96NV11718 \\ Controlled Copy No.: \\ Revision: 1 \\ Prepared by \\ Bechtel Nevada \\ Environmental Restoration
}

July 1998 


\section{STREAMLINED APPROACH FOR ENVIRONMENTAL RESTORATION WORK PLAN FOR CORRECTIVE ACTION UNIT 126: CLOSURE OF ABOVEGROUND STORAGE TANKS NEVADA TEST SITE, NEVADA}

Approved by: $\frac{Q_{\text {ayten }} \omega \cdot B_{\text {anow }}}{\text { fon L I Appenzeller-Wing, Project Manager }}$ Approved by: $\frac{\text { Runtec }}{\begin{array}{c}\text { Runore C. Wycoff, Projet Manager } \\ \text { Nevada Environmental Restoration Project }\end{array}}$
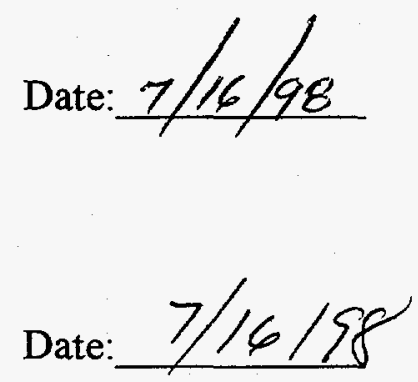


\section{TABLE OF CONTENTS}

ACRONYMS AND ABBREVIATIONS $\ldots \ldots \ldots \ldots \ldots \ldots \ldots \ldots \ldots \ldots \ldots \ldots$ vii

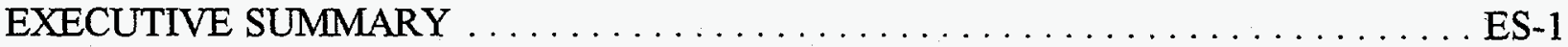

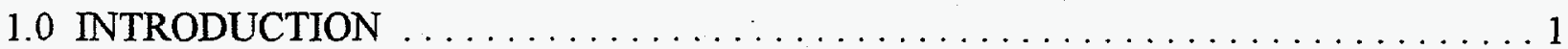

$2.0 \quad$ UNIT DESCRIPTION AND CLOSURE ACTIVITIES $\ldots \ldots \ldots \ldots \ldots \ldots \ldots$

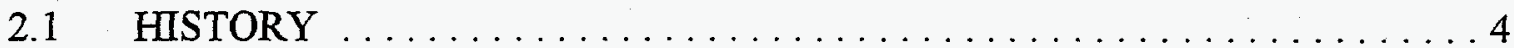

2.2 SITE LOCATION AND DESCRIPTION $\ldots \ldots \ldots \ldots \ldots \ldots \ldots \ldots \ldots$

2.2.1 CAS 25-01-01 - Sodium Hydroxide and Sulfuric Acid ASTs . . . . . . . 4

2.2.2 CAS 25-01-02 - Diesel AST (79,000 L [21,000 gal $]) \ldots \ldots \ldots \ldots$

2.2.3 CAS 25-01-03 - Diesel AST (15,000 L [4,000 gal]) . . . . . . . . . 7

2.2.4 CAS 25-01-04 - Charcoal Adsorption Furnace Tank . . . . . . . . . . 7

2.2.5 CAS 25-01-08 - Antifreeze, Water, and Nalcool Tank . . . . . . . . . 8

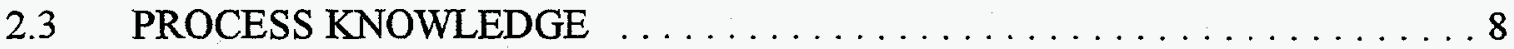

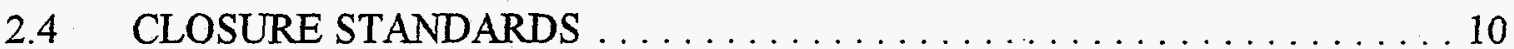

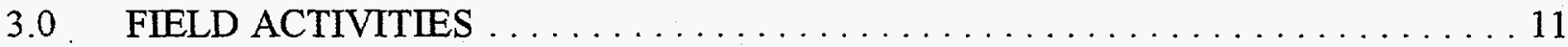

3.1 CONSTITUENTS OF POTENTIAL CONCERN $\ldots \ldots \ldots \ldots \ldots \ldots \ldots 11$

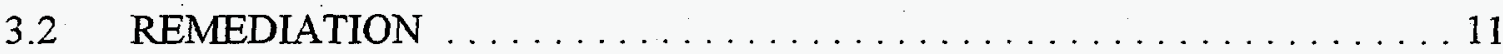

3.2 .1 Pre-field Implementation Activities $\ldots \ldots \ldots \ldots \ldots \ldots \ldots \ldots \ldots$

3.2.2.1 Tortoise Habitat and Endangered Species Investigation . . . . . 12

3.2.2.2 National Environmental Policy Act Documentation . . . . . . . 12

3.2.2.3 Site Specific Health and Safety Plan . . . . . . . . . . . . 12

3.2 .3 Field Activities . . . . . . . . . . . . . . . . . . . . . 12

3.2.3.1 CAS 25-01-01 - Sodium Hydroxide \& Sulfuric Acid ASTs

3.2.3.2 CAS 25-01-02 - Diesel AST (79,000 L [21,000 gal]) . . . . . 13

3.2.3.3 CAS 25-01-03 - Diesel AST (15,000 L [4,000 gal]) . . . . . . 14

3.2.3.4 CAS 25-01-04 - Charcoal Adsorption Furnace Tank . . . . . . . 14

3.2.3.5 CAS 25-01-08 - Antifreeze, Water, and Nalcool Tank . . . . . 14

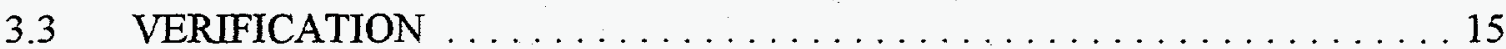

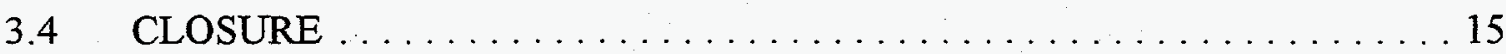

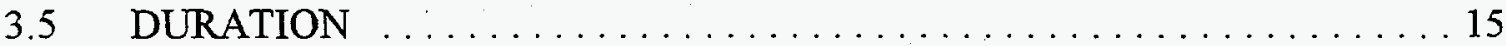

$4.0 \quad$ REPORTS AND RECORDS AVAILABIITY $\ldots \ldots \ldots \ldots \ldots \ldots \ldots \ldots \ldots$

5.0 INVESTIGATION/REMEDIATION WASTE MANAGEMENT $\ldots \ldots \ldots \ldots \ldots$

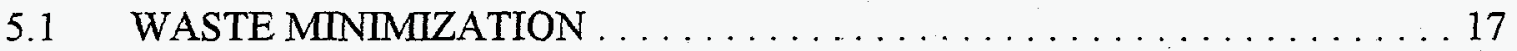




\section{TABLE OF CONTENTS (continued)}

5.2 POTENTIAL WASTE STREAMS $\ldots \ldots \ldots \ldots \ldots \ldots \ldots \ldots$

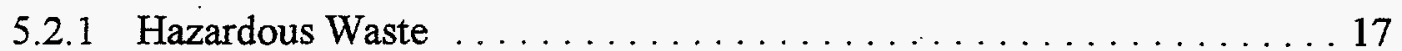

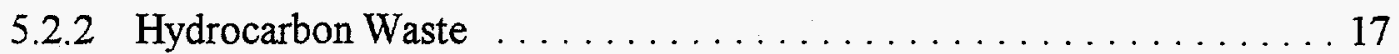

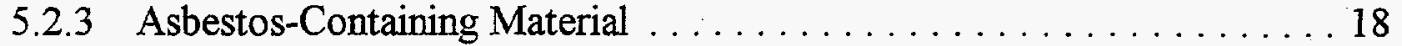

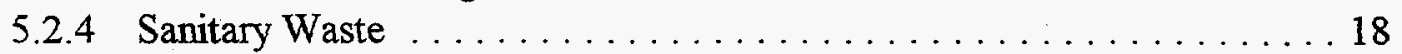

$6.0 \quad$ REFERENCES . . . . . . . . . . . . . . . . . . . . . . . . . 19

APPENDIX A -PROJECT ORGANIZATION.

APPENDIX B - CHEM:PLEX ${ }^{T M}$ ENVIRONMENTAL PRODUCTS, INC. LITERATURE

DISTRIBUTION LIST

\section{FIGURES}

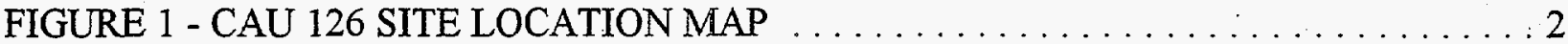

FIGURE 2 - ENGINE TEST STAND SITE VICINITY MAP $\ldots \ldots \ldots \ldots \ldots \ldots$

FIGURE 3 - CAU 126 -ENGINE TEST STAND CORRECTIVE ACTION SITES . . . . . 6

FIGURE 4 - BUILDING 4838 ANTIFREEZE, WATER, \& NALCOOL

TANK LOCATION

\section{TABLE}

TABLE 1 -SUMMARY OF CAU 126 CORRECTIVE ACTION SITES 


\section{ACRONYMS AND ABBREVIATIONS}

$\mathrm{ACM}$ asbestos-containing material

AST aboveground storage tank

CAS Corrective Action Site

CAU Corrective Action Unit

$\mathrm{cm} \quad$ centimeter (s)

DOE/NV U.S. Department of Energy, Nevada Operations Office

DQO Data Quality Objectives

ETS Engine Test Stand

FFACO Federal Facility Agreement and Consent Order

$\mathrm{ft} \quad$ feet

gal gallon (s)

SSHASP Site Specific Health and Safety Plan

in inch (es)

IT International Technology Corporation

L liter (s)

m $\quad$ meter $(s)$

$\mathrm{mg} / \mathrm{kg} \quad$ milligrams per kilogram

NDEP Nevada Division of Environmental Protection

NEPA National Environmental Policy Act

NTS Nevada Test Site

PPE Personal Protective Equipment

SAFER Streamlined Approach for Environmental Restoration

TPH total petroleum hydrocarbons 


\section{EXECUTIVE SUMMARY}

This plan addresses the closure of several aboveground storage tanks in Area 25 of the Nevada Test Site. The unit is currently identified as Corrective Action Unit 126 in the Federal Facility Agreement and Consent Order and is listed as having six Corrective Action Sites. This plan addresses the Streamlined Approach for Environmental Restoration closure for five of the six sites. (CAS 25-01-05 is within a radiological contamination area at Test Cell $\mathrm{C}$ and will be closed as part of another CAU.) Four of the CASs are located at the Engine Test Stand complex and one is located in the Central Support Area.

The sites consist of aboveground tanks, two of which were used to store diesel fuel and one stored Nalcool (an antifreeze mixture). The remaining tanks were used as part of a water demineralization process and stored either sulfuric acid or sodium hydroxide, and one was used as a charcoal adsorption furnace. Closure will be completed by removal of the associated piping, tank supports and tanks using a front end loader, backhoe, and/or crane. When possible, the tanks will be salvaged as scrap metal. The piping that is not removed will be sealed using a cement grout. 


\subsection{INTRODUCTION}

This plan addresses the closure of several aboveground storage tanks located in Area 25 of the Nevada Test Site (NTS). The unit is identified as Corrective Action Unit (CAU) 126 in the Federal Facility Agreement and Consent Order (FFACO) and is listed as having six Corrective Action Sites (CASs). This plan addresses the Streamlined Approach for Environmental Restoration (SAFER) closure for five of the six sites. (CAS 25-01-05 is within a radiological contamination area at Test Cell $\mathrm{C}$ and will be closed as part of another CAU.)

Four of the CASs are located at the Engine Test Stand (ETS) complex and one is located in the Central Support Area. The sites consist of aboveground tanks, two of which were used to store diesel fuel (CAS 25-01-02 and 25-01-03) and one stored Nalcool, an antifreeze mixture (CAS 25-01-08). CAS 25-01-08 no longer exists at the identified location in the Central Support Area and will be closed with no further action. The remaining tanks were used as part of a water demineralization process done in Building 3320 and stored either sulfuric acid or sodium hydroxide (CAS 25-01-01), and one was used as a charcoal adsorption furnace (CAS 25-01-04). Table 1 provides a summary and description of the tanks. Refer to Figures 1 for a site location map.

\section{TABLE 1 - SUMMARY OF CAU 126 CORRECTIVE ACTION SITES}

\begin{tabular}{|c|c|c|c|c|}
\hline 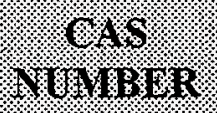 & (1) & 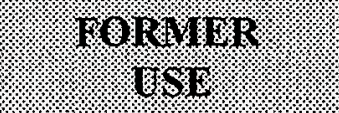 & 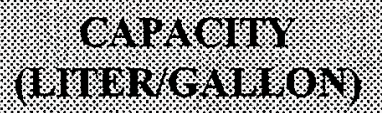 & 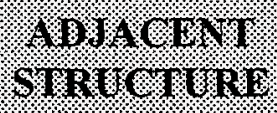 \\
\hline \multirow[t]{2}{*}{$25-01-01$} & $\mathrm{~T}-2002$ & Sodium Hydroxide & \multirow[t]{2}{*}{$19,000 / 5,000$ each } & \multirow[t]{2}{*}{ Building 3320} \\
\hline & T-2003 & Sulfuric Acid & & \\
\hline $25-01-02$ & $\mathrm{~T}-2001$ & Diesel Storage & $79,000 / 21,000$ & Building 3320 \\
\hline $25-01-03$ & $\mathrm{~T}-2401$ & Diesel Storage & $15,000 / 4,000$ & Building 3324 \\
\hline $25-01-04$ & D-2001? & $\begin{array}{l}\text { Charcoal } \\
\text { Adsorption }\end{array}$ & $5,300 / 1,400$ & Building 3320 \\
\hline $25-01-08$ & Unmarked & $\begin{array}{l}\text { Antifreeze, water, } \\
\text { and Nalcool }\end{array}$ & $300 / 80$ (estimated) & Building 4838 \\
\hline
\end{tabular}

The SAFER concept is implemented for this CAU because enough information exists about the nature and extent of contamination to propose an appropriate corrective action. The SAFER process combines elements of the Data Quality Objectives (DQO) process and the observational approach to help plan and conduct corrective actions. DQOs are used to identify the problem and define the type and quality of data needed to complete the investigation phase of the process. 


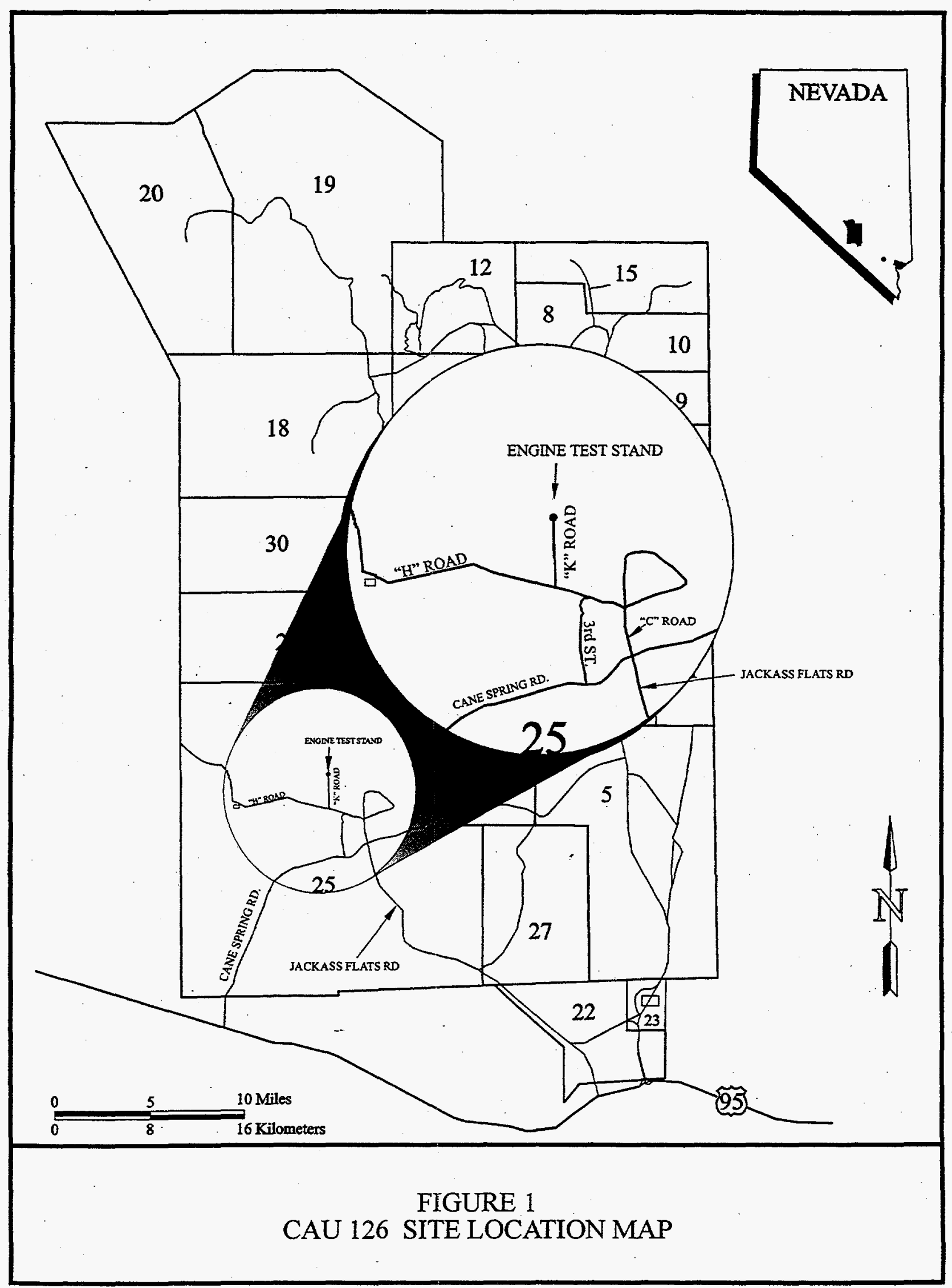


The observational approach provides a framework for managing uncertainty and planning decision making. The purpose of the investigation in the SAFER process is to verify the adequacy of existing information to implement the corrective action. The SAFER plan will identify decision points where DOE/NV will reach consensus with NDEP prior to beginning the next phase

The SAFER concept recognizes that technical decisions may be made based on incomplete, but sufficient, information, and the experience of the decision maker. Any uncertainties are addressed by documented assumptions that are verified by sampling and analyses, data evaluation, and on-site observations as planned activities progress, and by contingency plans as necessary. The remediation and closure may proceed simultaneously with site characterization as sufficient data are gathered to confirm or disprove the assumptions made in selecting the closure method. If, at any time during the site closure, new information is developed that indicates that the closure method should be revised, the closure activities will be redirected to more appropriately protect human health and the environment.

Closure will be completed by placing the sulfuric acid residue associated with CAS 25-01-02, in containers, and then removing the associated piping, tank supports and tanks from all of the sites. 


\subsection{UNIT DESCRIPTION AND CLOSURE ACTIVITIES}

\subsection{HISTORY}

The EST facility was designed for the testing of a downward firing Nuclear Engine for Rocket Vehicle Application-type engine. The ETS includes a test stand connected to a control point building by a tunnel. The tanks associated with Building 3320 (CASs 25-01-01, 25-01-02, CAS 25-01-04), the Utility Equipment Building, were used as part of a water demineralization process. Diesel tank T-2401(CAS 25-01-03) was used to support the emergency generators in Building 3324, the Emergency Generator Plant.

\subsection{SITE LOCATION AND DESCRIPTION}

Five of the tanks are located at the ETS facility in vicinity of Buildings 3320 and 3324 . One tank was located adjacent to Building 4338 in the Central Support Area. Refer to Figure 2 for a ETS site vicinity map and Figures 3 and 4 for photographs of the sites.

The scope of work is to close each CAS by removal. All ACM and associated piping or fixtures will be removed from the tanks. The sulfuric acid residue will be containerized. The tanks will be freed from their supports or piping. The surface piping will be cut as close to the ground or building face as possible. Remaining piping will be sealed with cement grout. The tanks will be transferred to salvage for resale or disposed of at the onsite sanitary landfill depending on the tanks former use and current condition.

Limited soil excavation will be done below tank T-2401 (CAS 25-01-03). Samples will be collected after removing the soil to ensure that all impacted soil above the Action Level has been removed. Additional samples will be collected beneath diesel tank T-2001 to determine if historical releases have impacted the underlying soils. If the presence of petroleum hydrocarbons is evident during sampling activities, limited backhoe excavation will be completed to remediate the release area.

\subsubsection{CAS 25-01-01 - Sodium Hydroxide and Sulfuric Acid ASTs}

CAS 25-01-01 consists of two 19,000-L (5,000-gal) ASTs. One was used to store sodium hydroxide and the other, sulfuric acid (T-2003). The two tanks were installed in the early 1960s and were used in conjunction with a water demineralization process in Building 3320 (IT, 1997a). Piping leading from the tanks proceed underground to Building 3320 . The sodium hydroxide tank is empty. The bottom of the sulfuric acid tank is severely corroded and a dried acid residue is present on the ground surrounding the tank and inside the tank to a thickness of approximately 15 centimeters $(\mathrm{cm})(6$ inches [in]). 


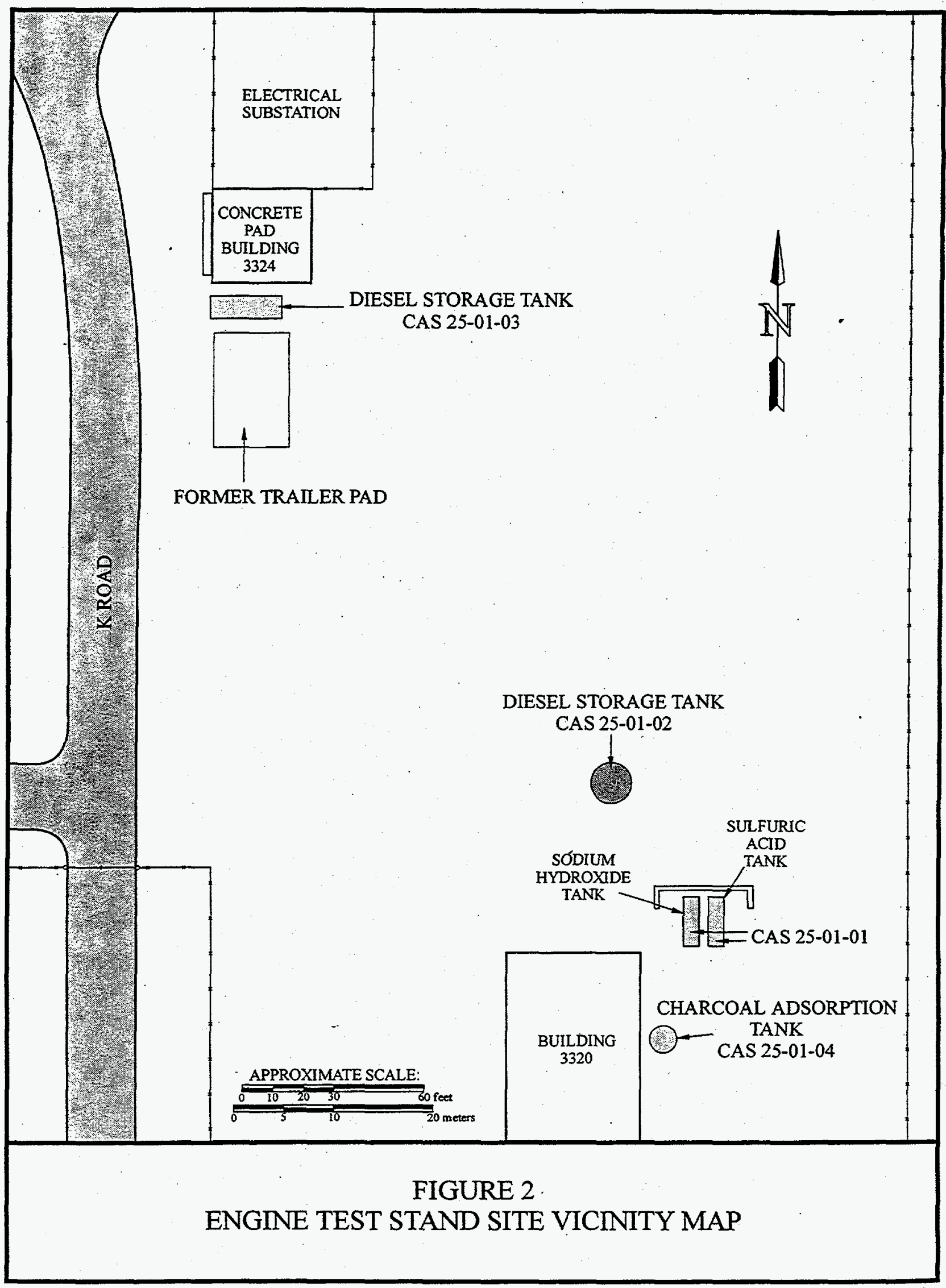




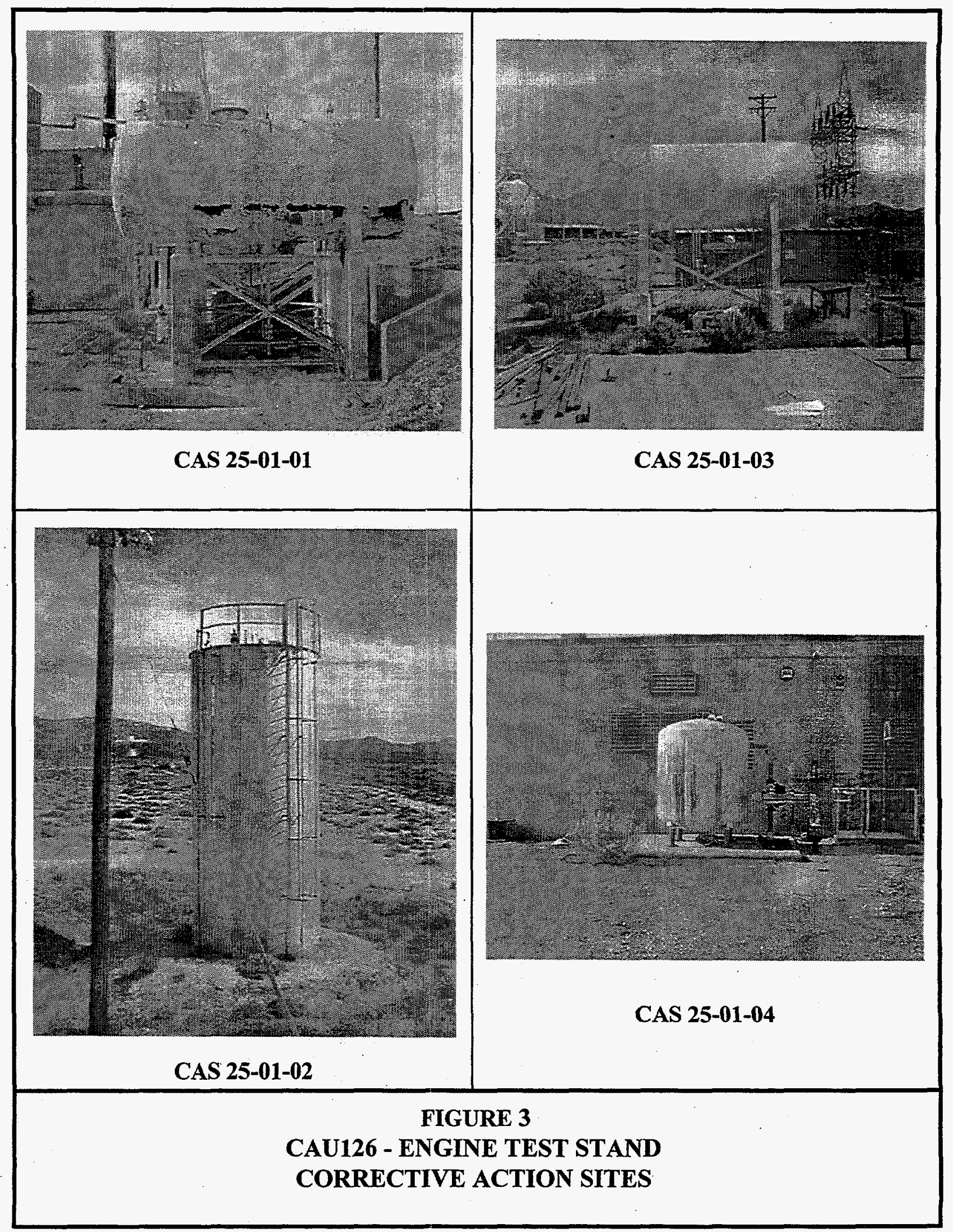


The insulation on the elbows of the aboveground piping associated with the sodium hydroxide tank is an apparent asbestos-containing material (ACM) and will be handled as such. The tank is wrapped with a fiberglass and canvass-type cloth coating. This material and the piping insulation in several other areas were sampled on May 11, 1998. Laboratory analysis confirmed that these items were not an ACM.

\subsubsection{CAS 25-01-02 - Diesel AST (79,000 L [21,000 gal])}

CAS 25-01-02 consists of one 79,000-L (21,000-gal) AST installed in the early 1960s. The tank is located approximately 70 feet north of Building 3320 and was used to store diesel fuel used in boilers (IT, 1998). The tank is currently empty and positioned vertically. A site inspection of the tank indicated that the tank interior does not contain any residue or sludge and is relatively clean. The tank bottom and associated piping is partially buried by an earthen berm. Valves are visible and protected by metal sleeve casings. There was no indication of hydrocarbon releases from the tank and the tank integrity was good. One composite gamma spectroscopy sample was collected from surface soil surrounding the tank on May 11, 1998. The results will be used as a screening measure for the soils prior to any excavation activity.

\subsubsection{CAS 25-01-03 - Diesel AST (15,000 L [4,000 gal])}

CAS 25-01-03 consists of one approximately 15,000-L (4,000-gal) AST installed in the early 1960s. The tank is located approximately 73 meters ( 240 feet) north-northwest of Building 3320. The tank is positioned approximately $1.8 \mathrm{~m}(6 \mathrm{ft})$ above the ground surface and was used to store diesel fuel to supply Building 3324 and nearby generators (IT, 1997b). Five, 2.5-cm (1in) lines extend from the bottom of the tank, in addition to a rubber hose, which was probably used as a water drain line. The tank is in good condition and is considered empty based on past site evaluations and Reynolds Electrical and Engineering Company (REECo) records (IT, 1997b). Preliminary surface soil samples were collected on May 11, 1998, for total petroleum hydrocarbons (TPH) and gamma spectroscopy analysis. Preliminary analytical results indicate the presence of TPH impacted soil above the State Action Level of 100 milligrams per kilogram $(\mathrm{mg} / \mathrm{kg})$.

The TPH samples were collected near the $2.5-\mathrm{cm}$ (1-in) piping, below the suspected fill line and near the hose drain line. The radiological sample was composited from surface soil on the four sides of the tank. Some soil discoloration was observed on the north side and partially underneath the tank. However, due to the degraded state of the asphalt surface adjacent to the tank it is suspected that the discolored soil is caused by the weathered asphalt.

\subsubsection{CAS 25-01-04 - Charcoal Adsorption Furnace Tank}

CAS 25-01-04 consists of one 5,300-L (1,400-gal) capacity tank identified as a "charcoal adsorption furnace" associated with the water demineralization process (IT, 1997c). The tank is situated atop a concrete pad located adjacent to Building 3320 (Figure 2). The exterior condition 
of the tank is good. It is not labeled, other than manufacturing information. There is a 10-cm (4in) utility water line feeding the tank, a $10-\mathrm{cm}$ (4-in) dechlorinated water line from the tank to the demineralization plant, and one 10-cm (4-in) pipe from the tank to a dirt-filled sump or drain just below the tank on the north side. The aboveground piping appears to be in good condition, however, the pipe elbows and joints are insulated with apparent ACM. The piping insulation in several other areas were sampled on May 11, 1998. Laboratory analysis confirmed that these items were not an ACM.

\subsubsection{CAS 25-01-08 - Antifreeze, Water, and Nalcool Tank}

CAS 25-01-08 consisted of one 300-L (80-gal) capacity storage container. The tank was originally identified at Building 4838, the former gas station, located in the Area 25 Central Support Area. A site visit by IT in July 1997, confirmed that the tank no longer exists at the site. Discussions with property management personnel indicated that the tank would not have been tracked with a property number since it did not cost enough to warrant tracking (IT, 1997d). A photograph of the tank, provided in the REECo Inventory of Inactive and Abandoned Facilities Waste Sites, shows that the tank was labeled as containing a mixture of antifreeze, water and Nalcool (REECo, 1991). Visible surface staining of the soil or concrete was not observed during the July 1997 visit by IT (IT, 1997d) or during the site visit done by Bechtel Nevada on May 18, 1998.

Since this tank has already been removed and there is a high degree of confidence that the tank contained only an antifreeze mixture, which is not a regulated material, it is proposed that the site be closed with no further action taken. A site photograph is provided in Figure 4.

\subsection{PROCESS KNOWLEDGE}

Based on the historical knowledge of each of the tanks' use and the limited extent of site characterization warranted, closure activities will be completed using the SAFER concept. Closure activities are based on the results of Preliminary Assessments done at each site, historical research, and review of engineering drawings. If, at any time during the site closure, new information is developed that indicates that the closure method should be revised, the closure activities will be redirected to more appropriately protect human health and the environment.

This plan was developed using information and guidance provided from the following documents:

- Nevada Environmental Restoration Project. Project Management Plan, Revision 0, DOE, 1994. 


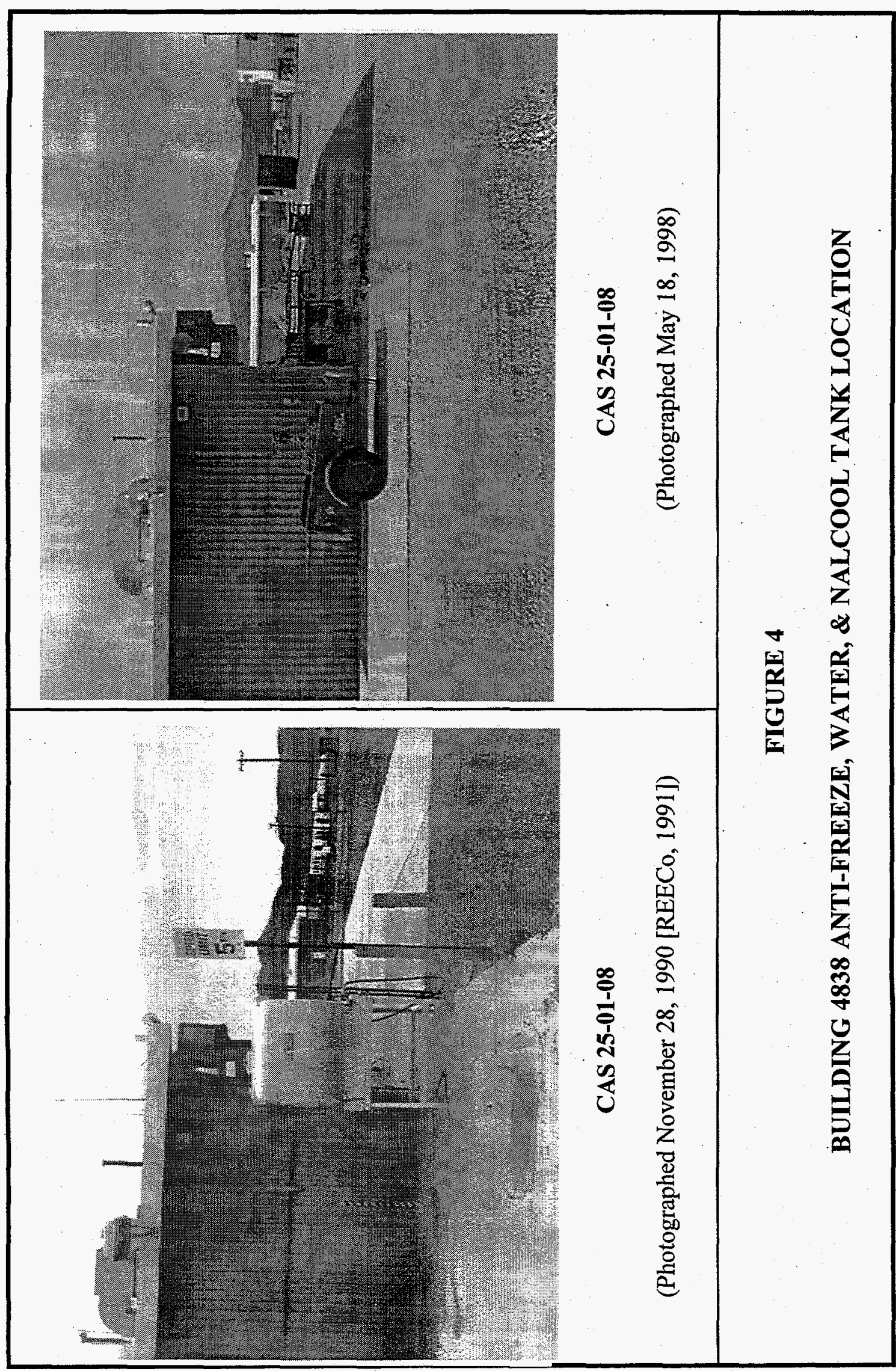


- Nevada Environmental Restoration Project, Industrial Sites, Quality Assurance Project Plan. Nevada Test Site, Revision 1, DOE, 1996.

- Preliminary Assessment for CAU No. 126: Area 25 Aboveground Storage Tanks, CAS No 25-01-01: Aboveground Storage Tanks (2) Nevada Test Site, Nevada, Preliminary Report, October, 1997.

- Preliminary Assessment for CAU No 126: Area 25 Aboveground Storage Tanks, CAS No. 25-01-02: Aboveground Storage Tank, Nevada Test Site, Nevada, January, 1998.

- Preliminary Assessment for CAUNo 126: Area 25 Aboveground Storage Tanks, CASNo. 25-01-03: Aboveground Storage Tank, Nevada Test Site, Nevada, Preliminary Report, October, 1997.

- Preliminary Assessment for CAU No. 126: Area 25 Aboveground Storage Tanks, CAS No. 25-01-04: Aboveground Storage Tank, Nevada Test Site, Nevada, Preliminary Report, October, 1997.

- Preliminary Assessment for CAU No. 126: Area 25 Aboveground Storage Tanks, CAS No. 25-01-08: Aboveground Storage Tank, Nevada Test Site, Nevada, Preliminary Report, October, 1997.

\subsection{CLOSURE STANDARDS}

The State Action Level of $100 \mathrm{mg} / \mathrm{kg}$ TPH will be used as the cleanup standard for CAS 25-0103 and, if applicable, for CAS 25-01-02. 


\subsection{FIELD ACTIVITIES}

\subsection{CONSTITUENTS OF POTENTIAL CONCERN}

The sulfuric acid tank associated with CAS 25-01-01, contains approximately $15 \mathrm{~cm}$ (6 in) of powdery residue. The residue will be placed into appropriate and compatible containers. There is also the possibility that chromium is present in the residue due to the reaction of the acid with the steel tank. The material will be handled as a hazardous waste pending analysis.

Two of the sites, CAS 25-01-01 and 25-01-04, have ACM on the elbows of the piping. This material will be encapsulated and removed by trained asbestos workers.

Soil samples collected below tank T-2401 (CAS 25-01-03) indicate the presence of TPH in excess of the State Action Level of $100 \mathrm{mg} / \mathrm{kg}$. There is also the potential that the soil beneath tank T-2001 (CAS 25-01-02) has been impacted by TPH. Impacted soils will be excavated and disposed of in the Area 6 Hydrocarbon Landfill. Verification samples will be collected to ensure that all soil exceeding the limit are removed.

\subsection{REMEDIATION}

The closure approach is based on the following:

- Closure consists of tank removal and limited site evaluation/sampling as warranted. There are no Resource Conservation and Recovery Act hazardous constituents associated with the closure of the tanks, other than the potential for chromium in the sulfuric acid residue.

- Based on historical use of the tanks as diesel storage or support of the water demineralization process, radiological hazards are not a concern for completing the tank closures. However, gamma spectroscopy samples were collected in the areas where soil removal is anticipated as a precautionary measured since historical activities at the ETS have involved testing with radioactive materials.

If a significant hydrocarbon release is identified during closure of one or both of the diesel tanks, a release CAS designation may be warranted. The new CAS designation could then be added to another CAU in Appendix II of the FFACO.

\subsubsection{Pre-field Implementation Activities}

The following activities have been completed or will be completed prior to the implementation of this plan: 
- Tortoise habitat and endangered species investigation.

- Preparation of National Environmental Policy Act (NEPA) documentation.

- Preparation of a SSHASP.

- A Cultural Resource Survey is not required since all work will be completed in previously disturbed areas. Off road driving in areas surrounding the site is not allowed.

\subsubsection{Tortoise Habitat and Endangered Species Investigation}

This site is located within the range of the desert tortoise. Therefore, a desert tortoise survey will be conducted. During all site activities, the terms and conditions of the NTS Biological Opinion (U.S. Fish and Wildlife Services, 1992) will be followed.

\subsubsection{National Environmental Policy Act Documentation}

A NEPA Environmental Evaluation Checklist will be completed prior to starting field activities.

\subsubsection{Site Specific Health and Safety Plan}

A Hazard Assessment and SSHASP have been prepared for this project. Personal protective equipment (PPE) will be dictated by the approved SSHASP. All site workers will be required to have current 40 -hour Hazardous Waste Worker Training as dictated by Occupational Safety and Health Administration Standard 1910.120. Personnel involved with the encapsulation and removal of the ACM will be trained and certified in asbestos handling and removal. Only properly trained/certified personnel will operate equipment and tools necessary to complete the closure.

\subsubsection{Field Activities}

Field activities will include the removal of five ASTs and limited soil evaluation, as warranted. The closure activities for each CAS will be completed as described in the following sections.

An Excavation Permit will be required prior to conducting site activities. An approved Excavation Permit indicates that every effort has been made to identify nearby utilities through the use of as-build engineering drawings, site visits, and an underground utility survey (Goldak). A Hot Work Permit will also be required for necessary cutting torch work required for tank removal.

\subsubsection{CAS 25-01-01 - Sodium Hydroxide \& Sulfuric Acid ASTs}

The sodium hydroxide tank and sulfuric acid tank and underlying support structure will be 
removed using a front end loader and/or backhoe. Prior to demolition, ACM on the piping and connection elbows will be bagged with plastic and removed by a trained and certified asbestos worker. If size or accessibility prohibits removal, the ACM will be treated with a product such as CHEM:PLEX ${ }^{\mathrm{TM}}$. CHEM:PLEX ${ }^{\mathrm{TM}}$ is a liquid product which has proven to permanently alter individual asbestos fibers up to a depth of $12.7 \mathrm{~cm}$ (5 in). The Material Safety Data Sheet and background literature is provided in Appendix B.

There is some solid residue remaining in the sulfuric acid tank and on the ground below the tank, and estimated 0.4 cubic meters [ 15 cubic feet]). This material will be placed in Department of. Transportation (DOT)-approved containers. Referring to the RCRA definition, the residue does not exhibit the characteristic of corrosivity because it is in solid form (40 Code of Federal Regulations [CFR] Part 261.22). However, the DOT proper shipping name will reflect the corrosive nature of the material and the containers will be compatible with this type of waste.

A sample of the residue was collected on June 15, 1998. The sample will be analyzed for metals using the Toxicity Characteristic Leaching Procedure (TCLP). There is the potential for chromium to be present in the residue because of its use in the production of steel. The containerized material will be handled properly, pending analysis.

A lead survey of the paint on the exterior of the tanks and support structure was done on June 15, 1998, using a Niton XL Spectrum Analyzer Lead Detector. All results were negative, i.e. no lead is present in the paint.

\subsubsection{CAS 25-01-02 - Diesel AST (79,000 L [21,000 gal])}

The 79,000-L (21,000-gal) former diesel tank will be removed using a crane. Prior to removal, the soil berm built up around the tank will be excavated to expose the piping, valves, and base of the tank. The piping will be removed and grouted where exposed at the surface. The tank base will be cut away using torches. Continuous monitoring for the lower explosive limit and oxygen levels will be completed prior to and during all cutting activities. The tank will be transferred onto a flat bed trailer truck. The tank will then be transported to salvage. Soil samples will be collected from below the base of the tank or adjacent to the concrete support pad, if applicable. Samples will be analyzed for TPH as diesel using U.S. Environmental Protection Agency (EPA) Method 8015, Modified, to determine if the tank had historically released petroleum hydrocarbons into the underlying soils. If a release is identified, in excess of the NDEP reporting limits of $95 \mathrm{~L}$ ( $25 \mathrm{gal}$ ) or 2.3 cubic meters ( 3.0 cubic yards), the spill will be reported to NDEP and limited backhoe excavation will be completed in an effort to remediate the spill. If the spill is remediated, based on field observation and instrumentation, verification soil samples will be collected and analyzed for TPH as diesel. If the spill is not able to be remediated using the onsite equipment, the spill will be added to another CAU. 


\subsubsection{CAS 25-01-03 - Diesel AST (15,000 L [4,000 gal])}

The 15,000-L (4,000-gal) former diesel tank will be removed using a crane and/or backhoe equipment. Prior to tank removal, the top portal of the tank will be removed to determine if residuals are present and to determine if tank cleaning is warranted. If cleaning is required prior to transporting to salvage, the tank will be triple rinsed using steam cleaning or pressure washing. Rinseate will e placed into 208-L (55-gal), DOT-approved metal drums free of dents or rust.

Preliminary analytical results from the samples collected from the soil beneath the tank indicate the presence of TPH above the State Action Level of 100 milligrams per kilogram $(\mathrm{mg} / \mathrm{kg})$. The associated tank piping will be removed and grouted at the ground surface. Soil samples will be collected after the tank has been removed and analyzed for TPH as diesel using U.S. EPA Method 8015, Modified, to determine if the tank had historically released hydrocarbons into the underlying soils. The samples will be collected from depths of approximately $0.6 \mathrm{~m}(2 \mathrm{ft})$ below ground surface from the west, center, and east areas below the former tank location. If a release is identified, in excess of the NDEP reporting limits of $95 \mathrm{~L}$ ( 25 gal) or 2.3 cubic meters ( 3.0 cubic yards), the spill will be reported to NDEP and limited backhoe excavation will be completed in an effort to remediate the spill. If the spill is remediated, based on field observation and instrumentation, verification soil samples will be collected and analyzed for TPH as diesel. It the spill is not able to be remediated using the on-site equipment, the spill will be added to another CAU.

\subsubsection{CAS 25-01-04 - Charcoal Adsorption Furnace Tank}

The 5,300 L (1,400 gal) capacity charcoal absorber furnace will be removed using a backhoe and/or forklift. The ACM located on the piping joints and elbows will first be bagged and cut where accessible or encapsulated using a product such as CHEM:PLEX ${ }^{\mathrm{TM}}$. All ACM removal activities will be completed by a trained and certified asbestos worker. The 10-cm (4-in) water lines above ground surface will be removed as close to the building or ground surface as possible. The remaining piping will be sealed at the exposed end using cement grout.

Once the piping has been removed from the tank it will be determined if the tank contents are empty or if there is any charcoal filter media remaining. If empty, the tank will be transported to salvage. If charcoal filter media remains, the tank will be disposed of in the onsite sanitary landfill. If required, the tank will be crushed to minimize void space prior to landfill disposal. Soil samples will not be collected in the vicinity of the charcoal adsorption tank. No hazardous materials/chemicals are associated with the process of this system which was used for demineralization of water.

\subsubsection{CAS 25-01-08 - Antifreeze, Water, and Nalcool Tank}

This tank has been removed and there are no hazards materials associated with this tank. No further action is warranted for this CAS. 


\subsection{VERIFICATION}

Since closure of CAU 126 consists primarily of removing the ASTs, limited clean-up verification is warranted. The only samples proposed are in the areas of the diesel tanks. If a historical hydrocarbon release is identified, limited soil excavation will be completed in an effort to remediate the site. If remediation can be completed using backhoe equipment, verification samples will be collected.

\subsection{CLOSURE}

Closure will be completed when all tanks have been removed, all debris has been removed from the sites, and all waste streams have been properly disposed of.

\subsection{DURATION}

The closure field activities are anticipated to begin within 45 calender days of NDEP approval of this plan and is outlined as follows:

- Submit Final SAFER Work Plan to DOE and NDEP (submittal planned for June 29, 1998. Review period is 30 days).

- Prepare for field work (tentative start and completion date - July 13 and July 30, 1998, respectively).

- Begin field closure activities within 45 days of submittal of Final SAFER Work Plan to NDEP. Tank removal and transport is anticipated to take four days.

- Submit Draft SAFER Closure Report to DOE (September 22, 1998).

The schedule will require modification if conditions exist that are outside the assumptions on which the schedule was developed. Flexibility has been placed in the project schedule to account for minor difficulties (weather, equipment breakdowns, personnel availability, etc.). DOE will keep the NDEP apprised of any condition that may impact the project schedule. 


\subsection{REPORTS AND RECORDS AVAILABILITY}

Upon completion of the tanks' removal, a closure report will be prepared and will include the following:

- Introduction (Purpose and Scope)

- Closure Activities (Description of activities)

- Waste Disposition

- Conclusions

This document is available in the DOE Public Reading Rooms located in Las Vegas and Carson City, Nevada or by contacting the DOE Project Manager. The NDEP maintains the official Administrative Record for all activities conducted under the auspices of the FFACO. 


\subsection{INVESTIGATION/REMEDIATION WASTE MANAGEMENT}

\subsection{WASTE MINIMIZATION}

Inspections of the tanks indicates that three of the five tanks can be removed and salvaged. This will eliminate the need to cut and crush the tanks for landfill acceptance, saving both labor costs, additional generation of PPE, and generating funds from the resale of the tanks.

\subsection{POTENTIAL WASTE STREAMS}

Waste minimization will be practiced when possible. The potential waste streams listed here do not include the tanks and associated steel which will be salvaged. Waste streams that are expected to be generated are listed below with a include

\subsubsection{Hazardous Waste}

The sulfuric acid residue will be containerized and treated as a hazardous waste pending analysis because of the potential chromium content. A sample was collected on June 15, 1998 and submitted for Toxicity Characteristic Leaching Procedure (TCLP) Metals. The results of this analysis will determine the disposal method.

The volume of residue remaining in the sulfuric acid tank and on the ground below the tank is estimated 0.4 cubic meters [ 15 cubic feet]). This material will be placed in Department of Transportation (DOT)-approved containers. Referring to the RCRA definition, the residue does not exhibit the characteristic of corrosivity because it is in solid form (40 Code of Federal Regulations [CFR] Part 261.22). However, the DOT proper shipping name will reflect the corrosive nature of the material and the containers will be compatible with this type of waste.

\subsubsection{Hydrocarbon Waste}

Soil samples collected on May 11, 1998 indicate the presence of petroleum hydrocarbons in the soil below the diesel tank identified as CAS 25-01-03 above the State Action Level. If additional hydrocarbon impacted soils are identified at the diesel tank locations, the excavated soil will be segregated onto plastic and covered pending analytical results. If determined that the soils sampled at the site contained petroleum hydrocarbon concentrations in excess of the State Action Level of $100 \mathrm{mg} / \mathrm{kg}$, the soils will be disposed of into the Area 6 Hydrocarbon Landfill. 


\subsubsection{Asbestos-Containing Material}

Some of the insulation on the sodium hydroxide tank (CAS 25-01-01) and the charcoal adsorption furnace (CAS 25-01-04) piping is ACM. This material will be encapsulated, bagged, and removed by trained asbestos workers. The ACM will be disposed of in the Area 23 Sanitary Landfill.

\subsubsection{Sanitary Waste}

Sanitary waste will consist primarily of demolition debris from the dismantlement of the tanks and their support structures. The waste will consist of concrete, piping, steel, etc. Also included in this waste stream will be CAS 25-01-04, the charcoal adsorption furnace. The contents of this tank is nonhazardous and will be disposed of in an onsite sanitary landfill. Waste will also consist of PPE used by the field crew while conducting asbestos removal and the sulfuric acid tank removal. Debris and PPE will be disposed of in an onsite sanitary landfill. 


\subsection{REFERENCES}

IT, 1997a, Preliminary Assessment for CAU No 126: Area 25 Aboveground Storage Tanks, CAS No. 25-01-01: Aboveground Storage Tanks (2) Nevada Test Site, Nevada, Preliminary Report, Las Vegas, Nevada.

IT, 1997b, Preliminary Assessment for CAU No. 126: Area 25 Aboveground Storage Tanks, CAS No. 25-01-03: Aboveground Storage Tank, Nevada Test Site, Nevada, Preliminary Report, Las Vegas, Nevada.

IT, 1997c, Preliminary Assessment for CAU No 126: Area 25 Aboveground Storage Tanks, CAS No. 25-01-04: Aboveground Storage Tank, Nevada Test Site, Nevada, Preliminary Report, Las Vegas, Nevada.

IT, 1997d, Preliminary Assessment for CAU No. 126: Area 25 Aboveground Storage Tanks, CAS No. 25-01-08: Aboveground Storage Tank, Nevada Test Site, Nevada, Preliminary Report, Las Vegas, Nevada.

IT, 1998, Preliminary Assessment for CAU No. 126: Area 25 Aboveground Storage Tanks, CAS No 25-01-02: Aboveground Storage Tank, Nevada Test Site, Nevada, Las Vegas Nevada.

REECo, 1991, Nevada Test Site Inventory of Inactive and Abandoned Facilities and Waste Sites, Areas 22-30. Volume 5 of 5 , Las Vegas, Nevada.

U.S. Fish and Wildlife Services, 1992, The Nevada Test Site Biological Opinion, Terms and Conditions. 


\section{APPENDIX A}

\section{PROJECT ORGANIZATION}


The following are the DOE/NV project contacts:

Runore C. Wycoff

Project Manger

Nevada Environmental Restoration Project

U.S. Department of Energy, Nevada Operations Office

P. O. Box 98518

Las Vegas, NV 89193-8518

(702) 295-2011

Janet L. Appenzeller-Wing

Project Manager

Industrial Sites Subproject

U.S. Department of Energy, Nevada Operations Office

P. O. Box 98518

Las Vegas, NV 89193-8518

(702) 295-0461

The identification of the project Health and Safety Officer and the Quality Assurance Officer can be found in the appropriate DOE plan. However, personnel are subject to change and it is suggested that the Project Manager be contacted for further information. The Task Manager will be identified in the FFACO Biweekly Activity Report prior to the start of field activities. 


\title{
APPENDIX B
}

\section{CHEM:PLEXTM ENVIRONMENTAL PRODUCTS, INC.}

\author{
LITERATURE
}




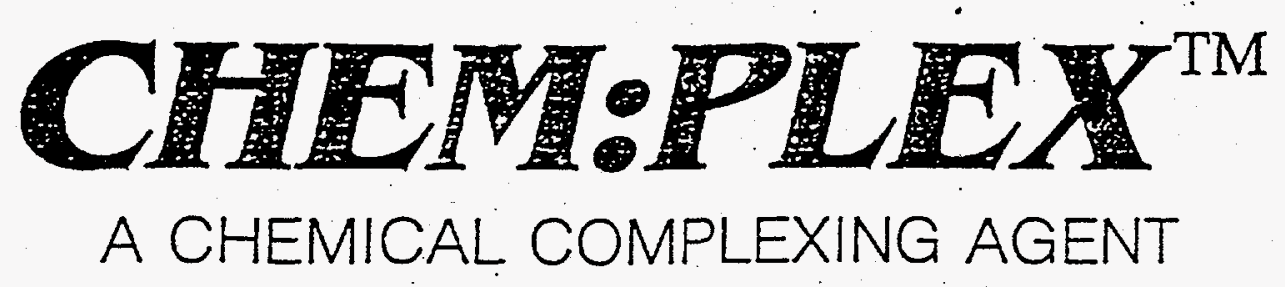

For Permanent Chemical and Physical Bonding of Asbestos Fibers

MAGNIFIED 500 TIMES

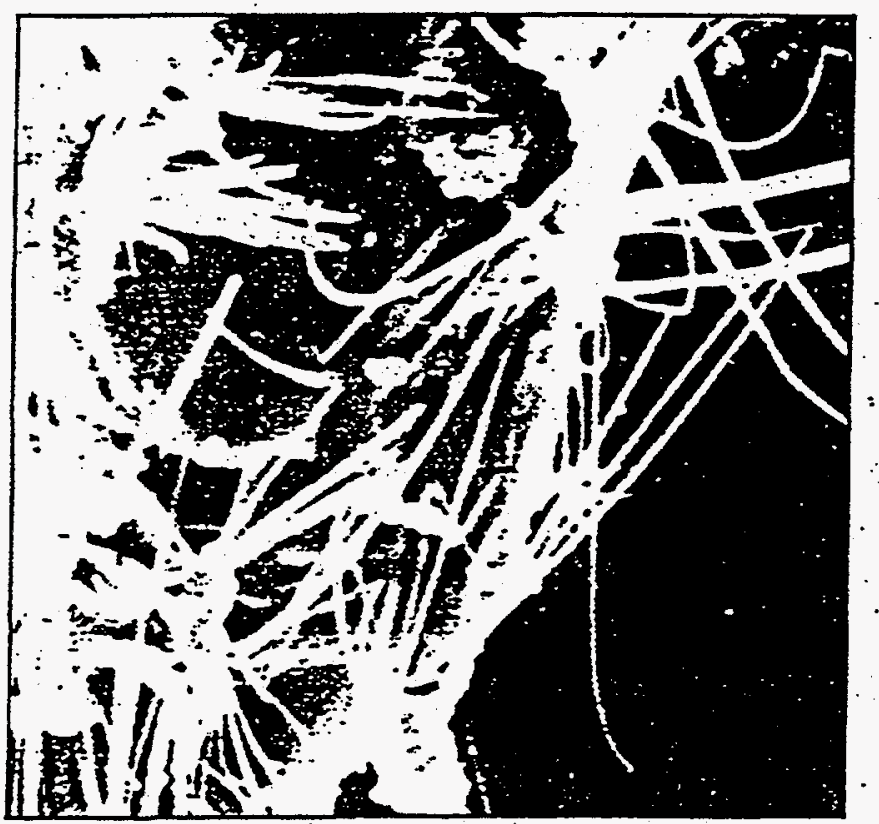

This is an untreated asbestos particle found on a shelf in a New Jersey library. The spiney dencirites clearly show the friability of asbestos.
MAGNIFIED 2000 TIMES

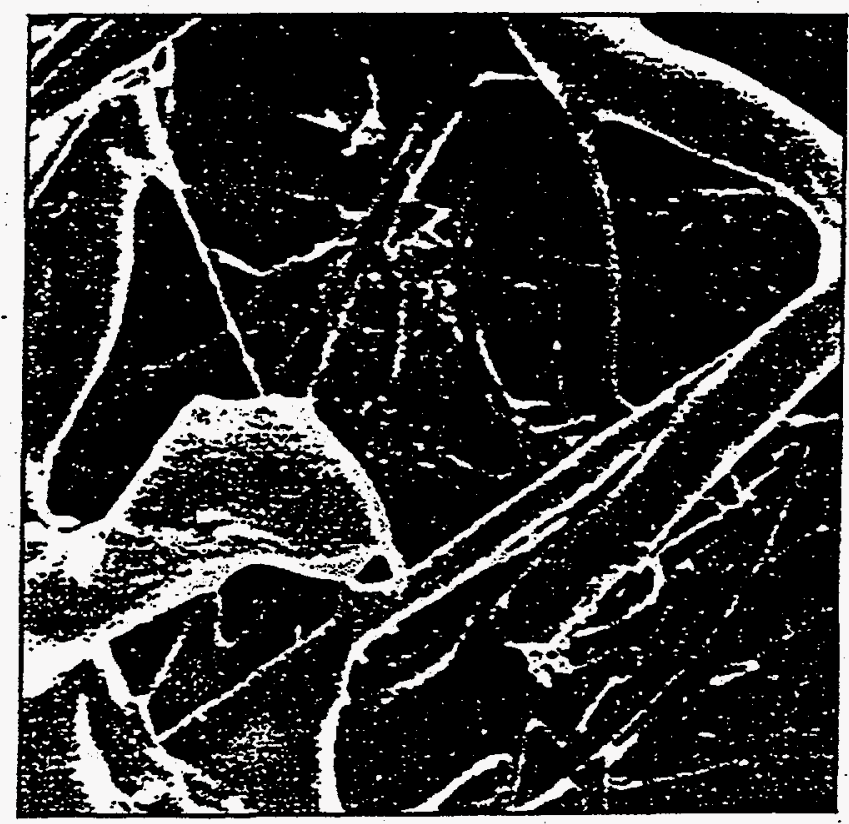

An asbestos particle after treatment with CHEM:PLEX. Notice that even on a microscopic scale the particle is completely enclosed.

\section{CTEMOPL ${ }^{\mathrm{TM}}$ \\ Environmental Products, Inc. 3405 Highway 33 \\ Neptune, New Jersey 07753 \\ 908-922-8857 FAX: 908-922-2504}


The CHEM:PLEX" system for permanent chemical complexing, and physical bonding of, individual asbestos fibers, has proven to be an extremely successful altemative to the costly removal or temporary encapsulation of asbestos containing materials (ACM). Even in those situations where the removal option for ACM is selected, CHEM:PLEX has no peer as a patented penetrant and wetting agent, and it significantly enhances the safety factor for the asbestos worker by reducing the atmospheric fiber count to almost nil-regardless of the type of asbestos (chrysotile; amostie, etc.). CHEM:PLEX is also the only patented "lock-down". agent for the permanent chemical bonding of residual asbestos fibers following removal of ACM.

The following Question and Answer format is presented for a better understanding of the asbestos problem and the CHEM:PLEX ${ }^{\pi}$ solution.

\section{What is asbestos, and why is it hazardous to humans?}

The word "asbestos" is simply a trade name, not unlike "Kleenex". Or "THERMOS.". It is used to describe a naturally occurring mineral called magnesium silicate. Because of it's fire retardant properties, it has been used in hundreds of products throughout the world, since well before the beginning of this century. Asbestos is rarely, if ever used alone. It is usually mixed with a binding material in almost all applications. It is the size (extremely small, measured in micrometers), shape (often needle-like) and weight (extremely light, can remain airbome for extended periods) of the individual asbestos fibers that cause them to be hazardous to humans. When, and as, these individual fibers break loose from the binding material, they are able to remain in the atmosphere and can be ingested, orally or nasally by humans. These fibers have the ability to lodge in the lungs or the mesothelium, and can have serious or fatal consequences. $\%$

\section{How are asbestos containing materials (ACM) remedied?}

The have an an a

There have been, essentially, four options for $A C M$ remedies

1. Removal. This option is usully recommended and/or required, when the ACM $\mathrm{AS}$ friable or otherwise likely to release fibers into the atmosphere The removal is usually accomplished by using a wetting agent such as "amended water" (water to which a surfactant has been added) to wet down the $A C M$, in an attempt to minimize the release of asbestos fibers into the atmosphere. As per EPA, OSHA \& other appropriate regulatory agencies, the $A C M$ is doubled bagged and removed to approved dump sites. One of the many problems with this method of removal, is that the ACM that has been saturated with water during removal will eventually revert to it's previously hazardous state when the water evaporates. If the double bags should in any way become compromised, hazardous asbestos fibers may be released into the atmosphere. This can be, and often is, an expensive option.

2. Encapsulation. This option is sometimes selected when ACM is intended to be removed at a later date. An "encapsulant," which is usually a paint-like formula, is sprayed, brushed or trowelled over the ACM (e.g.-asbestos containing ceiling insulation) in order to make a barrier coating. Encapsulants are usually effective, to the degree that they cover over the $A C M$, thus acting as a deterrent against the release of asbestos fibers. Encapsulants, however, add weight to the ACM and this added weight may cause the ACM to delaminate. If there is moisture on the substrate, encapsulants, which usually form a solid coating over the ACM, may prevent the moisture from evaporating. This too, can be a causative factor in delamination. Encapsulation tends to be thought of as a temporary solution, because the paint-like encapsulants will, over a period of time, dry, crack, flake or effloresce, and just like paint, they will require re-application. 
3. Barriers. In certain situations, a physical barrier is constructed over or around the ACM. This solution is generally looked upon as temporary in nature, as the ACM is left intact. It is believed, that, if the barriers are air-tight, the asbestos fibers will not enter the atmosphere. .

4. Operations \& Maintenance. 'Where ACM is considered to be in stable condition, and is not friable, and is in an area that is not subject to any significant human traffic, the "operations \& maintenance" $(O \& M)$ option is sometimes selected. In this option, the $A C M$ is inspected on a regular basis (visual inspection, air monitoring, etc.) to determine that it remains non-friable. Repairs to the ACM are made when, and as, discovered. Otherwise the ACM is left intact, untreated.

\section{What is CHEM:PLEX" and what is the CHEM:PLEX" solution?}

CHEM:PLEX products are unique, patented formulas; that have-been developed for the permanent alteration of individual asbestos fibers. Unlike encapsulants, which are usually too viscous for any significant penetration, the almost water-like viscosity of CHEM:PLEX ${ }^{\mathbf{m}}$ formulas have already been proven, in scientifically accepted, scanning and transmission electron microscopy protocols, to have penetrated asbestos containing ceiling insulation to a depth of five inches!

For many years, the unique insulating characteristics of asbestos remained a mystery. In the mid 1970's, a researcher and inventor by the name of John Apin (the inventor of the CHEM:PLEX formulas) was able to demonstrate that asbestos fibers are capillaries (see figure $\# \mathrm{~A}-1$; which is a cross-section of an asbestos fiber, magnified $60,500 \mathrm{x}$ ). The capillary furnished the asbestos fiber with the ability to insulate both theimally and acoustically by means of the air trapped in the hollow core of the fiber. The dead air. space has the interesting characteristic of bêng both dielectrically and thernally Iesistant to heat, sound and electricity. The principle is not unlike the dead air insulation of double-paned windows:-The effectiveness : of the CHEM:PLEX products was brought about by the careful selection and fortulation of components that are chemically and physically compatible with the asbestos fibers (magnesium silicate). The resultant formula is a colloidal liquid, whose particles are small enough to eniter and fill the capillary void. Because of the chemical compatibility; the silicatébased chEHEPLEX bonds itself permanently to the magnesium silicate. To assure permanency, a catalyst is added to the formula to facilitate crosslinking of the components. The asbestos fibers are boinded to each other and to the matrix: 30 .

The silicate to silicate bond alone, will render the asbestos fibers too heavy to become airbome, but because of their mineral composition, there is a natural britteness. It is for this reason that an elastomeric binder is incorporated as part of the CFEM PLEX formulas The elastomeric binder which is also a cross linking

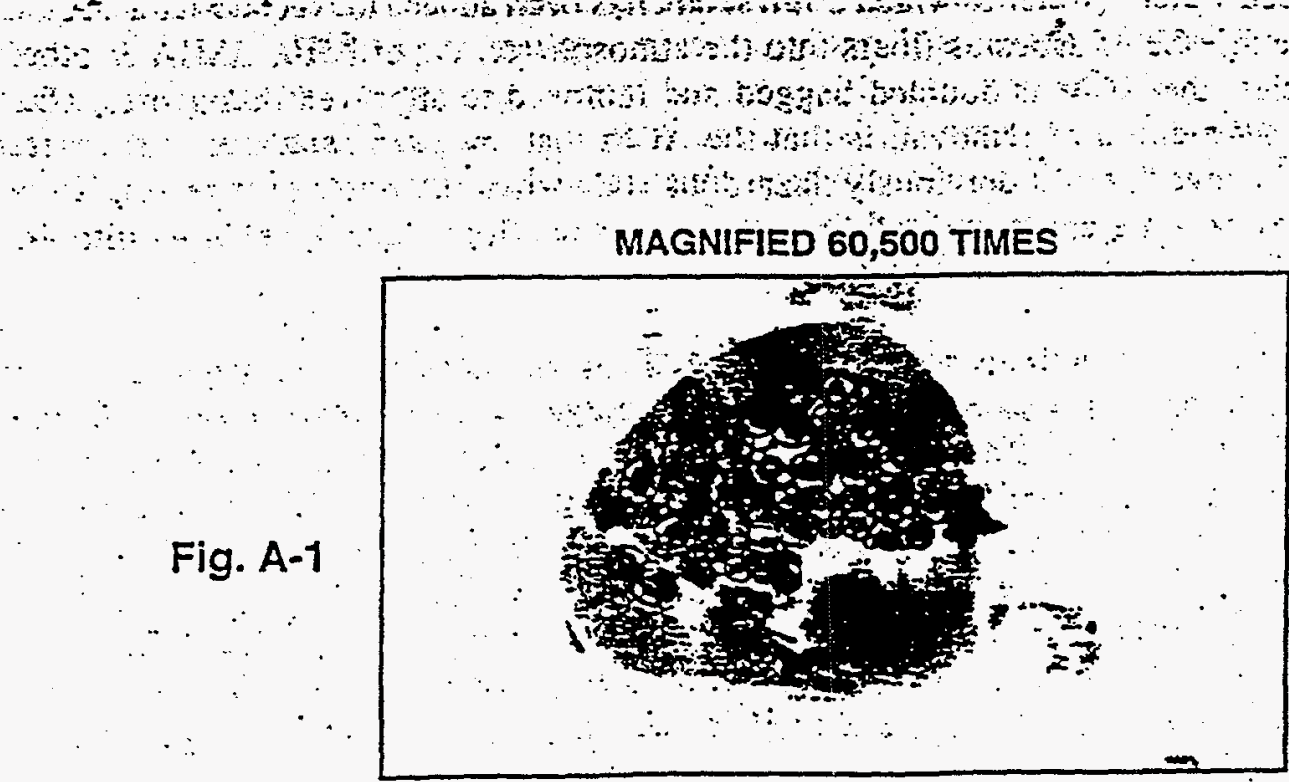

Even at a magnification of 60,500 it can be seen that the dendrite bundles of this CHEM:PLEX treated asbestos fiber are changed to round encapsulated fibers. 
agent, unites with the silicates as a result of the catalyst. The presence of the elastomer allows for coating the outer part of the fibers, giving them a flexible coating to enhance the integrity of the treated $A C M$, preventing fallout. The fire resistant qualities of the asbestos are unaffected, because the silicates are completely crystalline and are non-combustible. The mineral catalyst and elastomer contain a flame out additive which reduces the emission of toxic gases well below EPA requirements. CHEM:PLEX ${ }^{\text {m }}$ formulas are non-toxic, non-flammable, non-hazardous and lead-free. The insulating qualities of the treated ACM are only slightly affected. The porosity of CHEM:PLEX treated ACM is only reduced by about $6 \%$ in most cases.

CHEM:PLEX" remains the only patented chemical complexing/physical bonding agent for the permanent treatment of asbestos.

\section{WIII CHEM:PLEX ${ }^{\text {** }}$ work In every ACM situation?}

The simple answer is-maybe. The key to the effectiveness of the CHEM:PLEX formulas is the ability to come into contact with the asbestos fibers. This ability is affected by the density of the binding material(s). For example, CHEM:PLEX" is extremely effective on the "popcom" type asbestos containing ceiling insulation. It would not be as effective on in-tact asbestos floor tiles, because the density of the binder would severely inhibit penetration by CHEM:PLEX: or any other known asbestos penetrant. CHEM:PLEX"', however, unlike any other known penetrants or encapsulants, would chemically complex and bond to any surface asbestos fibers, regardless of the density of the binding material(s).

Why are there different CHEM:PLEX formulas and how are their applications determined?

There are four CHEM:PLEX formulations:

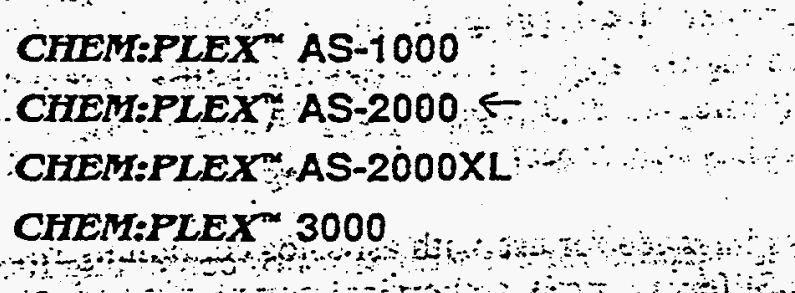

Each CHEM:PLEX product is silicate-based. Different additives are used to address specific needs and applications

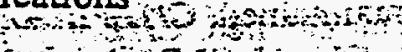

CHEM:PLEX AS-1000 is a silicate-based chemical complexing agent with enhanced penetration and wetting properties. It's primary function is for the safest and most effective removal of ACM. CHEM:PLEX AS-1000 has almost zero surface tension. Unlike "amended" water, it has been proven to penetrate ACM up to five inches deep. Unlike "amended water," CHEM:PLEX" AS-1000 permanently bonds to the asbestos fibers, making them too heavy to become airbome. Unlike "amended water," significantly less volume is required, almost entirely eliminating the type of damage that is caused by large volumes of water. Uniike "amended water," CHEM:PLEX" AS-1000 is equally effective on all types of asbestos, including amosite. Unlike "amended water," CHEM:PLEX" AS-1000 is first "misted" in the area of the ACM that is to be removed. This "misting" allows the CFEM:PLEX" AS-1000 to bond with any surface asbestos fibers, resulting in an almost nil fiber count before and during the actual removal process. The removed ACM weights considerably less than the "amended-waterlogged" ACM.

Unlike ACM that has been removed by using "amended water," CHEM:PLEX" treated ACM will not revert to it's previously hazardous state. The chemically complexed and physically bonded fibers will not become airbome if the double bags are compromised. In most situations where amosite type $A C M$ is to be removed, the high fiber count requires asbestos workers to utilize the most restrictive safety and respiratory equipment. In almost all of those situations, CHEM:PLEX ${ }^{m}$ AS-1000, properly misted and applied, can reduce the fiber count to almost nil, requiring less restrictive safety equipment, allowing for faster, time saving removal of the ACM: 
CHEM:PLEX“ Environmental Products, Inc. has had all of it's products tested for safety and performance, using scientifically accepted protocois, with the most sophisticated electronic monitoring and testing equipment, by world renowned institutions of leaming, governmental agencies and private laboratories. Regardless of the efficacy of CHEM:PLEX" products, it is always required to follow all local, state and federal statutory and regulatory rules, regarding the handling of hazardous materials and regarding air quality.

CHEM:PLEX AS-2000 is an all-purpose chemical complexing agent for use on asbestos fibers: It is intended for the permanent chemical complexing and physical bonding of asbestos fibers. It is recommended for use on ACM (regardless of the type of asbestos) that is penetrable and in good condition. It has been proven (see test data section) to penetrate and chemically complex/physical bond asbestos fibers in ACM up to five inches deep. The water-like consistency of CHEM:PLEX AS-2000 and the almost zero surface tension are some of the properties that enhance penetrability. Unilike "encapsulants," CHEM:PLEX" AS-2000 adds very litle weight to the ACM. Unlike "encapsulants,.. CHEM:PLEX" AS-2000 only minimally affects the porosity of the $A C M$, allowing moisture on the substrate to evaporate. Unlike "encapsulants,". CHEM:PLEX" AS-2000 will not dry, crack, flake or effloresce. Unilike

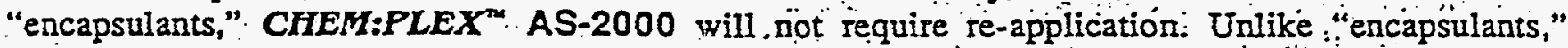
CHEM:PLEX" treated, chemically complexed, asbestos fibers will not revert to their previously hazardous state. Unlike "encapsulants," CHEM:PLEX" AS-2000 has been awarded a patent by the U.S. Patent Office as a chemical complexing/bonding agent for üse on asbestos fibers.

CHEM:PLEX AS-2000XL is a denser, more viscous formulation of CHEM:PLEX ${ }^{m}$.AS-2000. The "2000XL" is interided for use as a bridging agent. Although the "2000X $\mathrm{L}$ " is not a penetrant, it is a silicatebased chemical complexing agent, and it will chemically complex/physically bond to surface fibers of asbestos on ACM. It may be used as a bridging agent over ACM that has been treated with CHEM:PLEX AS-2000. It is most often employed as a bridging agent over pipe-lagging. In the ACM.pipe-lagging application, fiberglass re-wettable cloth is wrapped around the lagging, and the $2000 \mathrm{X}$ is then sprayed or brushed over it. As the fiberglass is silica based, the silicate based CHEM:PLEX AS-2000XL" will react chemically with it and bond in the same manner as it bonds with asbestos fibers (magnesium silicate).

$$
\text { ato }
$$

CHEM:PLEX AS-3000 is a silicate based formula that is intended for use with asbestos containing fire proofing materials on beams and structural members. The 3000 is strictly a chemical complexing agent, as it contains no elastomers. It is used on ACM that is in good condition and is not intended to be removed. The fire-proofing properies of the ACM is retained and fire insurance rates are maintained. CHEM:PLEX AS-3000 has the same penetration properties as the AS-1000 and AS-2000. CHEM:PLEX AS-3000 is also a rust inhibitive and will help to prevent furtier corrosion.

NOTE: Any CHEM:PLEX formula may be used as a "lock-down" for permanent chemical bonding of residual asbestos fibers, following removal of asbestos containing material. 


\section{CHEM:PLEX ${ }^{\top M}$ \\ Environmental Products, Inc. \\ 3405 Highway 33 \\ Neptune. New Jersey 07753 \\ 908-922-8857 FAX: 908-922-2504}

* + MATERTAL SAFEIY DATA SHEEEI FOR ASBESIIIIE - PEI OSHA 29 CFR 1910.1200

SDCIION I

Namufacturer: Chemplex Enviromental Products 3405 Higinay \#33 Neptume, New Jersey 07753

Emergency Phone:908-922-8857

Date: February 1, 1994

SECIION II

Hazarojous Ingredients/Identity Information

IIIGREDLENT:

CAS NUMBER PER CENT OSHA PEL MISC.

Water

Silicic Acid, Potassium Salt

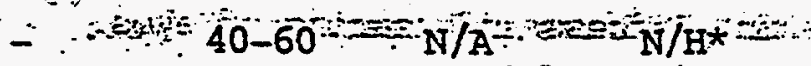

Tátex Emuĺsion: PROPRIETARY

Funed Silica (Hydrophyllic)
Surfactant: PROpRIETARY

$1312-76-1$

$25-50,5 \mathrm{mg} / \mathrm{m}^{3} \ldots \mathrm{N} / \mathrm{H}$

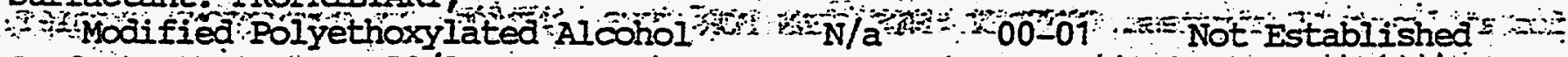

Surfactant Mixture: $50 / 50$ CAS $126-86-3$ \& 107-21-1

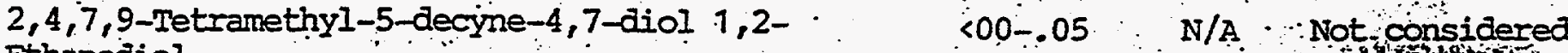
Ethanediol

Pa

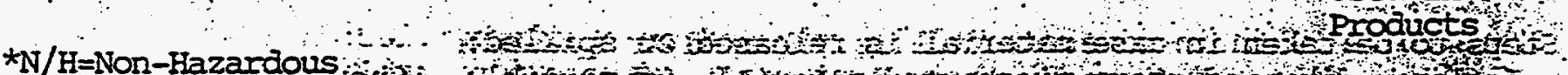

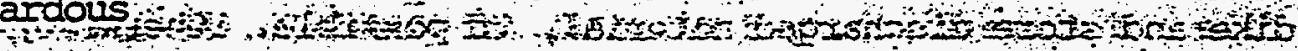

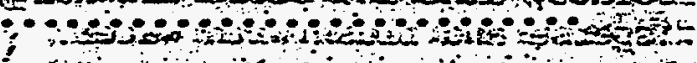

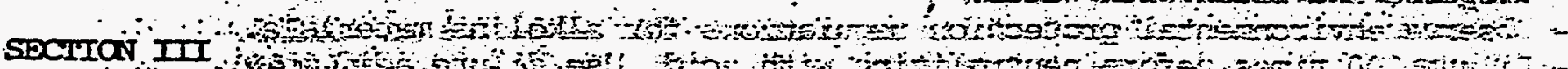

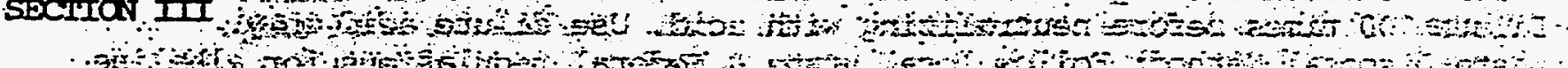
Physicalfchemical Characteristics

BOITTING POIINT: Ơंer $212^{\circ} \mathrm{F}$

VAPOR PRESSURE(mM Hg): .N/A

VAPOR DENSITY $(A I R=1): N / A$

SOLUBIIITY IN WATER: 98-100\%
SPECIFIC "GRAVITY " From $1 \% 1.1=1.4$ MELTING POINT: $32^{\circ} \mathrm{F}$

EVAPORATION RATE: AquEOÜS

APPEARANCE \& ODOR: Viscous Liquid; Colorless to Hazy; clear Chemical Odor

\section{SDCIION IV}

Fire and Explosion Hazard Data

FLASH POINT: Not Flamable

Special Fire Fighting Procedures: None known

Unusual Fire and Explosion Hazards: None Known 


\section{SECIION .V}

Reactivity Data

DO NOT MIX WILI ANY OLIIR MAUERTATS!

ENVIRONMENTAI HAZARD:" High alkălinity(pH) of undiluted or non-neutralized material is hamful to aquatic life.

STABIIITY: Stable; DO NOT FREXEZE! STORE ABOVE $32^{\circ} \mathrm{F}$

\section{SECIIIAN VI}

Health Gazara Data

ALKALINE MATERIAIS WIIL CAUSE IRRITATION AND DAMAGE WITH PROLONGED CONTACT TO EYES, SKTN AND MUCOUS MENBRANES. WEAR PROPER SAFETY EQUIPMENT.

CHRONIC HAZARD: No Known Chronic Hazards; Not listed BY OSHA, NIP; OI IARC:

SIGNS \& SIMPTONS OF EXPOSURE: Burinng or excessive itching in nose, throat or skin. Reäness and tearing of eyes.

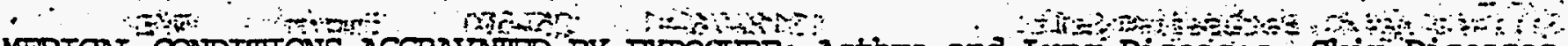
MEDICAI CONDITIONS AGGRAVATED BY EXPOSURE: Asthma and IUng Diseases, Sininiseases. FTRST ATD: Flush affected area with copious amount of water for at least 15 minutes. CoNTACT PHSTICon FOR

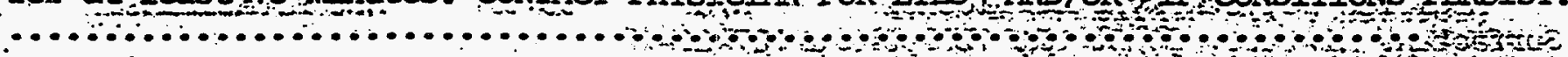

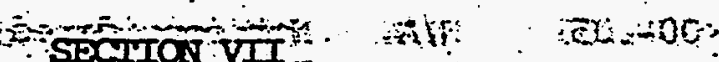
$\rightarrow$ P SECIION VII: Precautions for Safe Handing and uSE

Steps to betaken in case material is released or spilled:

- Isolate, dike and store discharged raterial, if possible otherwise,

- Observe environmental protection regulations for alkaline materials.

- Waste Disposal Method: Follow local state \& Federal regulations for alkaline materials.

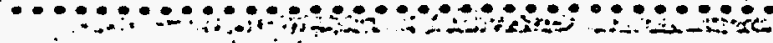

SECITON vII

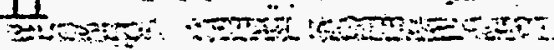

control Measures $=5 x$.

con

RESPIRATORY PROTECIION: Use NIOSH Approved MIST Respirator or better.

GLOVES: Rubber/Neoprene Recommended.

EYE PROIECTION: Chemical goggles and or face shield.

OTHER INFORMATION:

- Wash extensively after use. Alkaline materials may cause iritation to skin over long periods of time. Wash clothing well.

- Cover all GASS SURFACES; INCIUDING ENE GIASSEs, as proâct will react with glass (SITICA).

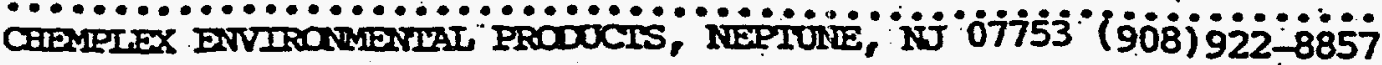




\section{DISTRIBUTION LIST}




\section{DISTRIBUTION LIST}

Copies

Paul Liebendorfer

Nevada Division of Environmental Protection

Bureau of Federal Facilities

333 West Nye Lane, Room 13B

Carson City, NV 89706-0866

Michael D. McKinnon

Nevada Division of Environmental Protection

Bureau of Federal Facilities

555 East. Washington, Suite 4300

Las Vegas, NV 89101

U.S. Department of Energy, Nevada Operations Office

Environmental Restoration Division

P. O. Box 98518

Las Vegas, NV 89193-8518

J. L. Appenzeller-Wing

C. W. Barrow

S. Bonnell

Public Reading Room

P.O. Box 98521 , M/S NLV040

Las Vegas, NV 89193-8521

Technical Information Resource Center

P.O. Box 98518 , M/S 505

Las Vegas, NV 89193-8518

U.S. Department of Energy, Office of Scientific and Technical Information

175 Oak Ridge Turnpike

P. O. Box 62

Oak Ridge, TN 37831 
Bechtel Nevada

P. O. Box 98521

Las Vegas, NV 89193-8521

Correspondence Control

D. K. Cowser

R. S. Remington

S. J. Nacht

A. L. Olson

K. A. Quintana 